that, to predict confidently, we need first to reach an understanding of the biological mechanisms of "natural" ageing and disease.

Evidence collected from Hiroshima and Nagasaki, and from the therapeutic irradiation of patients, reveals a clear connoxion between large acute doses of radiation and the subsequent onset of certain types of leukaemia. The only good evidence for radiation-provoked nonmalignant disease in man comes, however, from studies of mortality in US radiologists.

Experiments with inbred strains of mice leave no doubt that single acute, fractionated acute and chronic irradiations increase age-specific death rates from most fatal diseases, although the relative increase often differs from discase to disease and from strain to strain. Van Cleave gives us an excellent review of this voluminous evidence. Unfortunately, universal dose-response relations for lifeshortening have not cmerged. Lindop and Rotblat found a linear connexion when inbred mice, thirty days old, were given a single acute dose of $\mathrm{X}$-rays. Other workers, using different strains and conditions of irradiation, have found curvilinear dose-response relations.

What quantitative connexions hold between dose and pathology in man? Van Cleave does not provide the answers, but he surveys, clearly and accurately, most of the relevant observations obtained up to 1967 .

The commendably low price of this publication seems to be incompatible with a convenient binding: the physical effort of keeping the book open is sufficient to impair concentration.

P. R. J. BURCH

\section{FIGURING THE EARTH}

\section{Gemma Frisius, Tycho Brahe and Snellius and Their Triangulations \\ By N. D. Haasbroek. (Publication of the Netherlands} Geodetic Commission.) Pp. 119. (Rijkscommissie voor Geodesie: Delft, 1968.)

A prominent individual among those trying to determine the figure of the Earth was the Dutchman, Snellius or Snell, who connected two stations of measured astronomical latitude with a series of triangles deriving scale from a measured base; he thus computed the distance corresponding to a latitude difference, to derive a value for the Earth's radius. There is no doubt that Snellius was the first to apply the principles of triangulation to this problem; in this book Haasbroek considers to what extent Snellius actually invented triangulation, and assesses his debt to the sixteenth century predeccssors, Gemma Frisius and Tycho Brahe.

The short chapter on Gemma Frisius leaves little scope for controversy. Before he died in 1555, Gemma pub. lished in his Libellus a clear description of the principles of triangulation: how angles should be measured, and the need of "a large field, whereupon you can go hither and thither", a clear indication of a moasured base line. Haasbroek doubts the evidence of field work by Gemma to apply these principles, but is satisfied that when Tycho Brahe started his triangulation over the Sound in Denmark in 1578, he was acquainted with Gemma's writings.

The examination of 'Iycho Brahe's triangulation is very detailed. Angular observations, fully recorded, had been made with cross-staff or quadrant, and the errors inherent in the use of these simple instruments required investigation; in particular, the correction for the position of the observer's eye. Though the noed for this had been realized, it was not clear to what extent it had been actually applied. Tycho Brahe never fully computod his work, a major task in thoso days; it has been left to Haasbroek to carry out a full least squares adjustment, revealing a standard deviation of angle of $5^{\prime} \cdot 9$, a creditable result for the cross-staff. Because many prominent towers and spires still in existenee were fixed, their adjusted coordinates could be compared with modern trigonometry and the discrepancies shown diagrammatically; the only criticism made is of his derivation of scale.

Snellius receives still closer attention, and more than half the book is devoted to a scrutiny of his layout. Another least squares adjustment leads to exhibition of the discrepancies from modern work. Many factors complicated the scrutiny; although Snellius published an account of his work in Eratosthenes Batavus, there was no publication of subsequent work to correct detected crrors. Snellius's own copy includes corrections and extensions, but this copy suffered extensively from amendment at the hands of successors, which Haasbroek shows sometimes amounted to falsification. His verdict on Snellius as a "shoddy calculator" is in contrast to the memorial tablet which records that Snellius computed the first known three-point resection; but his field work was remarkable for the period. How many modern surveyors leave records that will not only survive such detailed analysis 350 years on, but also provide a subject for such a pains. taking and interesting investigation?

\section{A. BIDdue}

\section{TERRESTRIAL PLANETS}

An Introduction to Planetary Physics

The Terrestrial Planets. By William Kaula. (Space Science Text Series.) Pp. xvii +490. (Wiley : New York and London, January 1969.) 135s.

Professor KaUla's book, although wide in its embrace, is concise, coherent and as complete a work as one would expect to find penned by a single author with a penetrating scientific mind. Descriptivo sections-notably on the Moon, planets and meteorites-relate the facts and arguments simply. 'Throughout, the slant is on a firm, mathematical and modern approach to a question; and this is the principal value of the book. For example, problems related to convection, surface waves, anelasticity, hydromagnetism, planetary and satellite orbits and tides aro introduced on a sound footing; and this is one reason why the book will be particularly useful to students of astronomy, geophysics and astrogeology. A list of problems appears at the end of each chapter. References (although not always well chosen) are numerous and the indexes adequate.

This book is original, and it is, in my opinion, one of the best monographs on the terrestrial planets that has appeared. The individual user will find it well worth paying the rather high price for this excellent treatise.

(7. Fieldoer

\section{SOVIET SPACE RESEARCH}

\section{Handbook of Soviet Space-Science Research}

Edited by George E. Wukelic. Pp. xx+505. (Gordon and Breach: New York and Iondon, September 1968.) $245 s$.

ThIs is really a collection of interpreted statistics of Soviet space science and technology rather than a hand. book on the subject. It contains no information on the theory of flight and the design of rockets and spaceshipsapparently this was not the purpose of the authors. But as a well-edited and systematized collection of facts and descriptions of spaceships, equipment and of the observational data obtained, the book is full of valuable information. Aerospace science and technology has advanced so rapidly in the Soviet Union, Sovict space exploration is 